\title{
Reduction of rejection of cylinder blocks in a casting unit: A six sigma DMAIC perspective
}

\author{
Surjit Kumar Gandhi*, Anish Sachdeva and Ajay Gupta
}

\begin{tabular}{|c|c|}
\hline$\overline{C H R O N ~ I ~ C L E ~}$ & A B S T RACT \\
\hline $\begin{array}{l}\text { Article history: } \\
\text { Received: October } 22018 \\
\text { Received in revised format: No- } \\
\text { vember } 192018 \\
\text { Accepted: January } 72019 \\
\text { Available online: } \\
\text { January } 72019 \\
\text { Keywords: } \\
\text { Six sigma } \\
\text { DMAIC } \\
\text { Preventive and corrective ac- } \\
\text { tions } \\
\text { Rejection rate }\end{array}$ & $\begin{array}{l}\text { Six-Sigma approach is a systematic and scientific operations management methodology } \\
\text { aimed at achieving major enhancements in production process through the elimination of } \\
\text { waste. In this case, a casting unit manufacturing cylinder blocks has been selected which } \\
\text { was experiencing a rejection rate as high as } 30 \% \text { due to formation of blowholes, other than } \\
\text { the surface. The main objective of this paper is to identify various causes of occurrence of } \\
\text { blowholes and recommend corresponding remedies to counter these defects by systematic } \\
\text { implementation of DMAIC cycle. Both preventive and corrective actions have been recom- } \\
\text { mended to reduce the blowholes and overall improvement is validated through two-propor- } \\
\text { tion test. Results of investigation demonstrated the net significant reduction of blowholes } \\
\text { defect from } 28,111 \text { to } 9,708 \text { parts per million, which results in the net annual savings of INR } \\
12,56,640 \text {. }\end{array}$ \\
\hline
\end{tabular}

\section{Introduction}

If an existing process is not meeting customer specifications, use of five-phase Six Sigma methodology, also called DMAIC process can be made for better effectiveness and efficiency of production process, which ultimately leads to achieve higher productivity. These 5 phases are:

- Define: In this phase, the problem is explicitly defined and requirements of the customers are identified. The define phase sets the expectations of the improvement of project and maintenance of focus of Six-Sigma strategy on customers' requirement.

- Measure: The measure phase identifies the defects in the product, gathers valid baseline information about the process and establishes improvement goals.

- Analysis: The analysis phase examines the data collected to generate a prioritized list of sources of variation. It is the key component of any defect reducing program. This is the stage at which new goals are set and route maps are created for target performance level.

- Improve: The optimal solution for reducing variation or mean deviation is determined and confirmed in the improve phase. The objective of this phase is to confirm the key process variables, quantify their effects on the critical to quality (CTQ) features, and use of brainstorming, etc.

\footnotetext{
* Corresponding author.

E-mail address: skgandhi21@gmail.com (S. K. Gandhi) 
- Control: The final stage of Six Sigma implementation is to hold the gains that have been obtained from the improve stage. Hence, in this stage, the new process considerations are documented and frozen into systems so that the gains become permanent (Jaglan et al., 2013).

Different phases of Six- Sigma DMAIC approach are shown in Fig. 1.

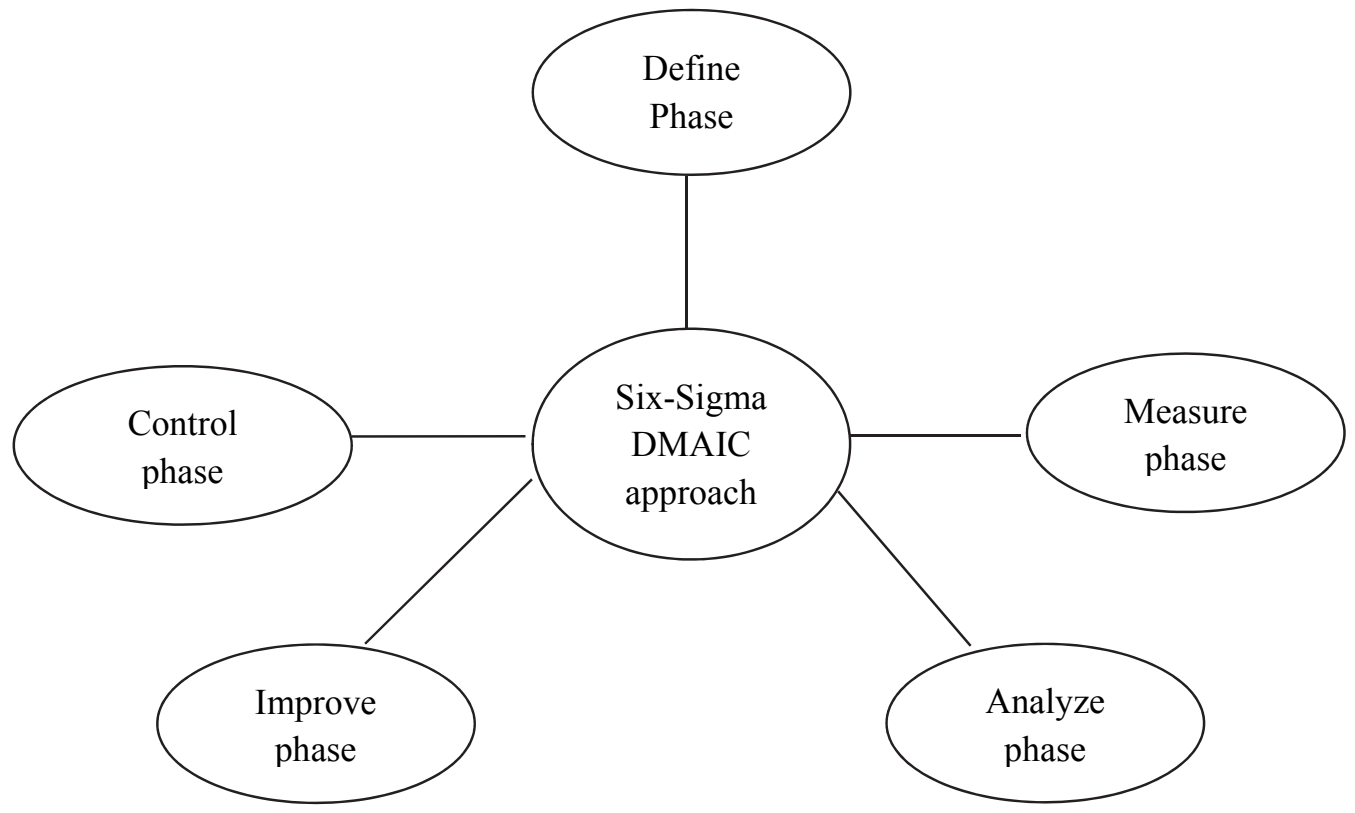

Fig. 1. Phases of Six-Sigma DMAIC approach

In the mid-1980s, Motorola created and used a statistics-based methodology called Six-Sigma to improve the performance of its processes (Snee, 2010). Six-Sigma is named after the process that has six standard deviations on each side of specification window (Chen et al., 2007). The discipline of Six-Sigma is particularly good for organizations seeking both bottom line improvement and defects reduction (Hu et al., 2005). In a Six-Sigma project, the team's problem solving efforts depend heavily on the use of a stepwise problem solving DMAIC (Choo et al., 2007). The prime benefit is 'elimination of subjective decision making by reduction in opportunities to commit mistakes' (Maleyeff \& Kaminsky, 2002). Many researchers have found that Six-Sigma can increase competitive capability of an organization (Banuelas et al., 2005).

The applications of Six-Sigma are reported in literature in all kinds of processes. Antony et al. (2012) reported Six Sigma applications in manufacturing, service and transactional environments. Tolga Taner et al. (2007) presented five case studies in healthcare to show the performance improvement accomplished by Six-Sigma. Six-Sigma is a well-structured and documented program that can help an organization achieve expected goals through continuous improvement. Six-Sigma can reduce defects to as low as 3.4 parts per million in an organization (Singh \& Khanduja, 2010). The aim of this study is to reduce high rejection rate experienced by a leading casting industry situated in northern India. Further, this study aims to investigate probable causes so that one can easily analyze and understand the real causes for blow holes.

\section{Literature review}

Table 1 presents a brief chronological summary of the salient studies in the area of application of Six-Sigma conducted in casting units over the last few years. 


\section{Table 1}

Key studies pertaining to Six-Sigma in manufacturing organizations

\begin{tabular}{|c|c|c|}
\hline S. No. & Author (Year) & Focus area and select contributions \\
\hline 1. & Tiwari et al. (2016) & $\begin{array}{l}\text { - The authors performed a case study in Indian foundry industry to explore the success of six sigma meth- } \\
\text { odology. } \\
\text { They followed Six-Sigma approach to reduce the rejection rate in the green sand casting process. In ad- } \\
\text { dition, response surface methodology was employed in 'Improve phase' to develop an empirical model } \\
\text { which correlated the casting process variables with the desired quality characteristics. } \\
\text { The developed model was further utilized to optimize the process parameters to minimize the casting } \\
\text { rejection. The results showed that after the implementation of Six-Sigma, the rejection rate reduced by } \\
25.44 \% \text {. }\end{array}$ \\
\hline 2. & $\begin{array}{l}\text { Pandey and Jain } \\
(2016)\end{array}$ & $\begin{array}{l}\text { - The authors conducted a case study in a casting industry suffering owing to poor quality and productivity } \\
\text { due to low quality sand being used in traditional process practices being employed and controlling a } \\
\text { number of process parameters involved. Their recommendations improved the sand quality and reduce } \\
\text { the defects. } \\
\text { - They used analysis of variance as optimization technique using MINITAB as software. }\end{array}$ \\
\hline 3. & Patil et al. (2015) & $\begin{array}{l}\text { - The researchers carried out a case study for a green sand casting production unit by using Six-Sigma } \\
\text { methodology and combined design of experiments (DOE) and ANOVA techniques to bring down the } \\
\text { defects in the Transmission Case. } \\
\text { - The authors used SPSS v } 21 \text { to correlate process parameters with number of defects and defectives. }\end{array}$ \\
\hline 4. & $\begin{array}{l}\text { Al-Refaie and Al- } \\
\text { Hmaideen (2014) }\end{array}$ & $\begin{array}{l}\text { - The researchers attempted to implement the Six-Sigma approach to raise the performance of traditional } \\
\text { compression method with two parameters - weight and hardness. } \\
\text { - During analyze and improve phases, designed experiments utilizing the Taguchi's L27 array } \\
\text { used in conjunction with grey relational analysis model. }\end{array}$ \\
\hline
\end{tabular}

5. Singh and - The study focused on scrap reduction in Indian small-medium foundry units (nearly $95 \%$ of all foundries).

Khanduja (2014) - $\quad$ They advocated that for global competitiveness, Indian industries need overall operational and service excellence and extensively engage Quality Circles, TQM and ISO Certifications. However, these methods have failed to deliver required performance over the last decade or so.

- The authors noted that it seems a comprehensive quality approach like 'Six- Sigma' is not fully explored among Indian industries. Overall sigma level was raised by 0.24 by reducing the scrap of a non-ferrous piston foundry from $22 \%$ to $10 \%$ after successfully implementing the DMAIC methodology.

6. Gijo and Sarkar - The researchers applied Six-Sigma methodology for improving quality in a large wing energy enterprise in India.

- They employed the scientific approach in areas of fabrication, commissioning and servicing of windmills sector.

7. Kumar et al. (2013) - The researchers implemented Six-Sigma approach to improve the green sand casting process.

- $\quad$ They analyzed important process parameters of the melt shop using Taguchi function of DOEx and proposing a process to minimize the casting defects and improve the sigma level of the industry.

8. Kumara and - The authors concluded that DMAIC is a technological process-driven, multi-contoured approach to improve process, reduce costs and increase profit and this methodology is used in small-scale industries and conducted taking the example of a hydraulic jack production unit by reducing manufacturing cost.

- Implementation of Six-Sigma helped improving Z-bench $\sigma$ from 2.21 to 5.64 and brought out net annual saving of Rs. 1,92,900.

9. Jaglan et al. (2013) - The authors developed a process chart for analysis phase of Six-Sigma methodology in an Indian large scale thermal power plant.

- $\quad$ The researchers identified Tripping as the major Critical-to-Quality issue during auditing of capacity at the selected power plant.

10. Mahdi and Almsafir - The authors concluded in their review study that central theme of employing $6 \sigma$ is to obtain sustainable competitive advantage for the manufacturing organization.

- In first section they described phases of $6 \sigma$ implementation. In second section, they churned out attributes of competitive advantage as- Process Efficiency, Effectiveness, knowledge creation and quality costing.

11. Shafer and Moeller - The researchers determined the impact of $6 \sigma$ on organizational performance and related it with employee (2012) involvement and top management support.

- The standard regression weight was calculated to measure influence of $6 \sigma$ upon corporate performance, but was not found to be significant.

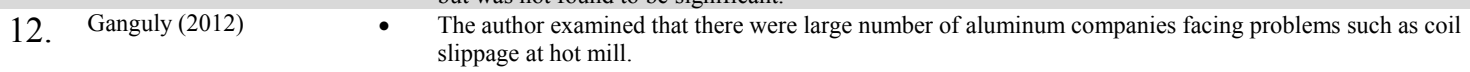

- The DMAIC study was implemented and $70 \%$ heat losses were reduced by installing monitor on coil rolling in process.

13. Matathil et al. - The practitioners in this study brought more than $88 \%$ reduction in scrap cost within six months of work with many tangible and intangible benefits including increased future business.

- It was concluded from the study that the actual quality is lying with manufacturing process and any complicated problem can be solved by systematic application of DMAIC.

14. Soti et al. (2011) - The authors postulated that $6 \sigma$ is a systematic and scientific methodology which excludes probability of making errors and thus consequently leads to business excellence.

- They determined 12 barriers in implementation of $6 \sigma$ from literature and categorized barriers into 3 classes of strategic, tactical and operational ones.

15. Kumar et al. (2011) MIC-MAC analysis was conducted to evaluate driving power as well as dependency of these barriers.

- The authors conducted a case study in a foundry unit with multi-objectives of defect reduction, productivity enhancement and quality improvement.

- The practical runs were conducted on shop floor for the differential housings. The methodology resulted in improved quality and enhanced stability.

16. Kovach et al. $\quad$ - The researchers aimed at providing engineering students with knowledge of Quality and Six Sigma prin(2011) ciples and the ability to solve practical engineering problems gives employers a workforce with the necessary skill sets while also making the graduating students more employable. 


\section{Table 1}

Key studies pertaining to Six-Sigma in manufacturing organizations (Continued)

\begin{tabular}{|c|c|c|}
\hline S. No. & Author (Year) & Focus area and select contributions \\
\hline 17. & $\begin{array}{l}\text { Sambhe and } \\
\text { Dalu (2011) }\end{array}$ & $\begin{array}{l}\text { - The authors selected a group of Indian medium scale automotive units for thorough implementation of Six- } \\
\text { Sigma and appreciate the outcomes. } \\
\text { Different existing frameworks for Six-Sigma were reviewed with respect to Indian automotive industry and } \\
\text { proposed Six-Sigma as an impeccable growth model for such organizations in the current competitive era. }\end{array}$ \\
\hline 18. & $\begin{array}{l}\text { Aboelmaged } \\
(2011)\end{array}$ & $\begin{array}{l}\text { - The author insisted upon two pronged Six-Sigma approach viz. DMAIC for traditionally existing practices } \\
\text { being followed in the units. } \\
\text { In comparison the second methodology namely DMADV, is useful for new processes under design- with } \\
\text { phases of defining, measuring, analyzing, designing and validation. }\end{array}$ \\
\hline 19. & $\begin{array}{l}\text { Kumaravadivel } \\
\text { and Natarajan } \\
(2011)\end{array}$ & $\begin{array}{l}\text { - The researchers implemented DMAIC study is implemented in the manufacturing process, and the process } \\
\text { level was increased from } 3.32 \text { by significant } 5 \% \text {, and when the DMAIC study is applied on the job satisfaction } \\
\text { project, job satisfaction in employees increased to } 83 \% \text {. }\end{array}$ \\
\hline 20. & $\begin{array}{l}\text { Azis and Osada } \\
(2010)\end{array}$ & $\begin{array}{l}\text { - The authors determined Six-Sigma to have a positive and comprehensive influence to impact change man- } \\
\text { agement } \\
\text { - Six-Sigma harmonizes and synergizes team of employees involved in its implementation. }\end{array}$ \\
\hline 21. & $\begin{array}{l}\text { Pulakanam and } \\
\text { Voges }(2010)\end{array}$ & $\begin{array}{l}\text { - The authors narrated that since } 2004 \text {, a number of empirical studies have been undertaken in different coun- } \\
\text { tries and industry sectors to address gaps in knowledge of Six-Sigma adoption. } \\
\text { The majority of these studies are reviewed and summarized in this paper and concluded that Six-Sigma is } \\
\text { only a distant second to Lean in terms of popularity. During the period } 2003 \text { to 2007, Six-Sigma was imple- } \\
\text { mented in } 5 \% \text { to } 15 \% \text { of the organizations. }\end{array}$ \\
\hline 22. & $\begin{array}{l}\text { Salah et al. } \\
(2010)\end{array}$ & $\begin{array}{l}\text { - The authors proposed a combined and integrated fit of Six-Sigma and lean thinking and chalked out a plan } \\
\text { for the same leading to KAIZEN. }\end{array}$ \\
\hline 23. & $\begin{array}{l}\text { Chandna and } \\
\text { Chandra (2009) }\end{array}$ & $\begin{array}{l}\text { - The authors reported the DMAIC study of crankshaft being manufactured in a leading organization in } \\
\text { Tatanagar, India. They focused on reducing the casting defects which creep in such as lap, un-filling, and } \\
\text { total length undersize was identified with the help of Pareto diagrams. } \\
\text { Recommendations and remedial solutions were presented during DMAIC study, leading to a defect reduction } \\
\text { from current } 2.43 \% \text { by } 2.22 \% \text {. }\end{array}$ \\
\hline 24. & $\begin{array}{l}\text { Thomas et al. } \\
\text { (2008) }\end{array}$ & $\begin{array}{l}\text { - The researchers applied DMAIC approach in a casting shop to find out the casting defects such as blow holes, } \\
\text { miss run, slag inclusion, and rough surface. These defects were reduced by changing the moisture content in } \\
\text { sand. } \\
\text { After implementation of the DMAIC, the rejection rate was reduced from } 7.53 \% \text { to } 2.8 \% \text { and this leads to } \\
\text { cost saving of } 5.5 \text { lakh annum approximately. }\end{array}$ \\
\hline 25. & $\begin{array}{l}\text { Shah and Ward } \\
\text { (2007) }\end{array}$ & $\begin{array}{l}\text { - The authors advocated the use of DMAIC methodology may influence customer satisfaction positively and } \\
\text { may lead to improved supplier management. } \\
\text { They recommended the use of soft practices like service quality as integrated effort with manufacturing strat- } \\
\text { egy of unit. }\end{array}$ \\
\hline 26. & Camgoz (2007) & $\begin{array}{l}\text { - The researcher described how DMAIC is not only the 'best-in-class' industrial philosophy, but a commitment } \\
\text { to business excellence and perfection leading to continuous quality improvement. }\end{array}$ \\
\hline 27. & Bendell (2006) & $\begin{array}{l}\text { - The review study concluded that the available literature lacks compatibility of Six-Sigma and lean ap- } \\
\text { proaches. } \\
\text { There is hardly a common and combined methodology available in literature to synergic implementation of } \\
\text { these strategies. }\end{array}$ \\
\hline 28. & $\begin{array}{l}\text { Antony et al. } \\
(2005)\end{array}$ & $\begin{array}{l}\text { - The authors } 9 \text { critical success factors for service sector namely-strong leadership and management commit- } \\
\text { ment, organizational culture change, aligning Six-Sigma projects to corporate business objectives, selection } \\
\text { of team members and team work, Six-Sigma training, understanding the DMAIC methodology-tools-tech- } \\
\text { niques and key metrics, selection of projects, effective project handling, with customer satisfaction and ac- } \\
\text { countability as outcome parameters. }\end{array}$ \\
\hline 29. & $\begin{array}{l}\text { Sokovic et al. } \\
(2005)\end{array}$ & $\begin{array}{l}\text { - The authors contended that process design and development involving Six-Sigma is a very important phase } \\
\text { in the preparation of automotive-part production. }\end{array}$ \\
\hline 30. & $\begin{array}{l}\text { Rajagopalan et } \\
\text { al. (2004) }\end{array}$ & $\begin{array}{l}\text { - The researchers emphasized Six-Sigma as an intelligent blending of the wisdom of an organization, with } \\
\text { proven statistical tools, to improve both the efficiency and effectiveness of the organization for the whole- } \\
\text { hearted satisfaction of the customer. } \\
\text { The success of Six-Sigma program hinges on the sequence of many Six-Sigma elements of a model for im- } \\
\text { plementation, they concluded. }\end{array}$ \\
\hline 31. & $\begin{array}{l}\text { Edgeman and } \\
\text { Bigio (2004) }\end{array}$ & $\begin{array}{l}\text { - The authors described Six-Sigma as a management tool of achieving path breaking results. } \\
\text { The aim is institutionalization of a rigorous, disciplined, factual methodology combining principles of scien- } \\
\text { tific management with almost perfect processes aligned to deliver goods and services to the delight of cus- } \\
\text { tomers. }\end{array}$ \\
\hline 32. & Goh (2002) & $\begin{array}{l}\text { - The author provided a framework for effective Six-Sigma implementation program and indicated the realistic } \\
\text { contributions of the program. }\end{array}$ \\
\hline 33. & $\begin{array}{l}\text { Coronado and } \\
\text { Antony (2002) }\end{array}$ & $\begin{array}{l}\text { - The authors identified } 12 \text { typical CSFs from their review of Six-Sigma textbooks and other related literature. } \\
\text { These CSFs include issues relating to management involvement and commitment, cultural change, commu- } \\
\text { nication, organization infrastructure, training, business strategy, customers, human resources and suppliers, } \\
\text { understanding tools and techniques with Six-Sigma, project management skills, project prioritization and se- } \\
\text { lection. }\end{array}$ \\
\hline 34. & Tennant (2001) & $\begin{array}{l}\text { - The researcher, in order to reduce the defects, focused on critical success factors and took preventive action } \\
\text { against any failures and also minimized the mechanical faults by the proper training of maintenance team. } \\
\text { Inspection is also very important factor for checking quality of product before going to customer. That is why } \\
\text { it is necessary to focus more work for removing the defects in the process and reduce the risk for any com- } \\
\text { plaint of product }\end{array}$ \\
\hline
\end{tabular}

\section{Problem Statement}

DMAIC is one of the Six-Sigma methodologies used to improve quality by reducing defects using scientific process improvement techniques. In this project, we dealt with high rejection rate of cylinder block casting. The overall foundry rejection of Simpson $\mathbf{3 0}$ cylinder block was observed to 
be high. It is on the $1^{\text {st }}$ priority in plant Cylinder blocks family as expressed in severity table. The average foundry rejection of this product is 84,000 PPM against the target of 55,000 PPM due to which the unit was experiencing a loss of INR 20.2 Lakh/ Annum. The major defect observed was formation of blowholes, which is a difficult to understand and comprehend phenomenon. At times, the rejection rate due to occurrence of blowholes was as high as $30 \%$. Once the blowholes form in castings (other than surface blowhole), the casting suffers irreparable damage. Thus, changes were desired to be made in sand, metal or tool design as corrective measures.

Many researchers have tried to explore the causes of blowholes formation, though mostly efforts available in literature are in form of case studies addressing particular causes of blowhole occurrence, and a comprehensive conjoined effort is missing. This study thus makes an attempt to identify potential probable causes, correlating them so that one can easily analyze and understand the real causes for blow hole. The foundry rejection was observed for last 1 year, although lot of actions taken during last one year, but problem still persists. Because if cause is unknown, solution is unknown.

\subsection{Objectives of the Study}

- To determine the root and potential causes of formation of blowholes.

- To recommend possible remedial actions.

- To document a knowledge pool related to blowholes.

\section{DMAIC Cycle}

This section describes the systematic application of DMAIC methodology in the casting unit under study which includes the preventive and corrective actions to improve the manufacturing system processes. The foundry rejection was observed for the last 1 year. Although a lot of rule of thumb actions had been taken during last one year; but problem still persisted. Since the cause is unknown, as well as solution is unknown; so DMAIC methodology has been applied.

\section{Define Phase}

The Define Phase is about coming up with a focused problem statement and a supporting measure of success or failure. To set the context and objectives for the project- Define the problem, improvement activities and opportunities, setting the project goals, and identifying customer requirements. The 4-bore cylinder block is one of main parts of an internal combustion engine comprising of crank case, cylinder head, passages for inlet and exhaust and coolant. For defining the problem, CTQ (Critical To Quality) is identified from the voice of customer and CTP (Critical to Process) is identified from the voice of business, which are to be attended on priority to sustain in the business and shown in Fig. 2.
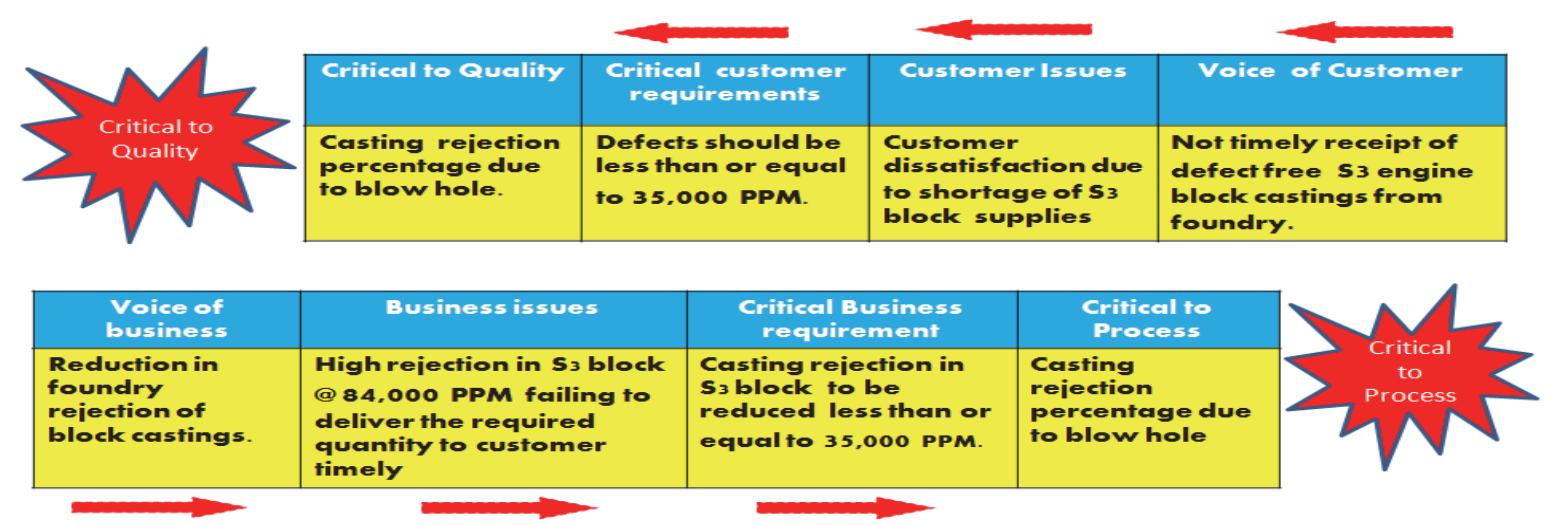

Fig. 2. Critical To Quality / Critical to Process Chart 
In the Fig. 3, the Pareto analysis of S3 block was carried out for the period April-June 2017. As per 80:20 concept, the defects are marked in graph. It is inferred that Pareto analysis prioritizes 'Blowholes' defects as top priority contributing to $36 \%$ of overall defects, followed by 'Sand', 'Broken Water Jacket' and 'Unfused Chaplet, being 27\%, 11.2\%, and 7.2\% respectively. In this study, focus was laid on 'Blowholes' defect as it is Voice of Customer (VOC) and voice of business as well.

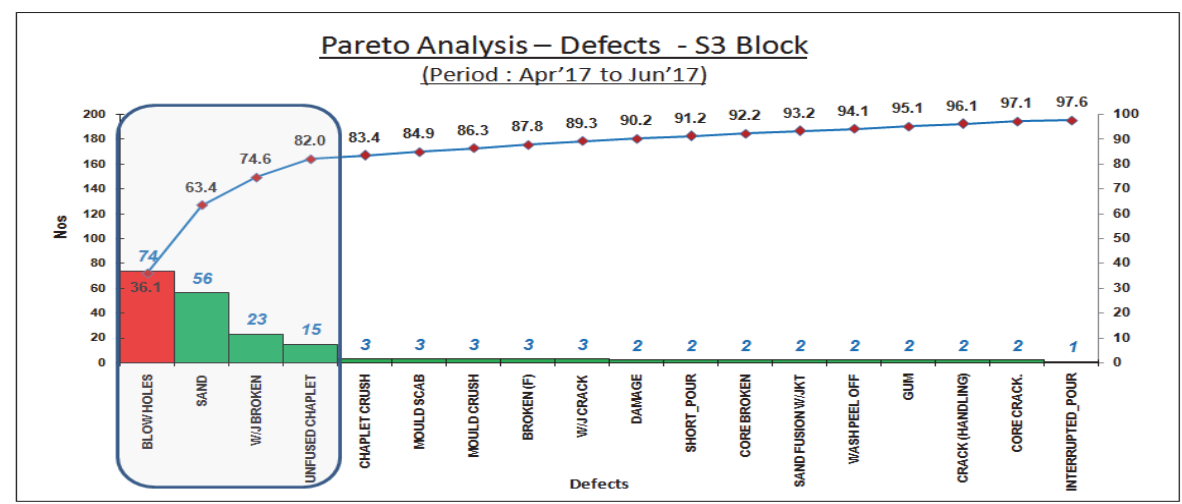

Fig. 3. Understanding the Problem - Pareto Analysis of S3 Block

The case supports business objective, the plan, impact of plan and sigma level were defined in opportunity statement, current level and target level were noted in statement of objectives, scope and plan of project, and team details were defined and sigma level was calculated. Table 2 shows Sigma level calculations of cylinder block measured for the period April-June'17. Whereas the number of units processed are 2,440 Nos., and the defects observed are 205 Nos.; the DPMO is 84,016 and current Sigma Level is calculated as 2.88 .

Table 2

Sigma Level Calculations - Apr'17 to Jun'17

\begin{tabular}{lc}
\hline Number of Units Processed & 2440 \\
\hline $\begin{array}{l}\text { Total Number of Defects Made } \\
\text { (including defects made and later fixed) }\end{array}$ & 205 \\
Number of Defect Opportunities per unit & 1 \\
Defects per million opportunities & 84016 \\
Sigma level & 2.88 \\
\hline
\end{tabular}

Fig. 4 shows the foundry stage rejection PPM trend plotted for the months April-June, 2017. The gap in April'17 is 34,000 PPM, in May'17 is 28,200 PPM and in June'17 is 24,000 PPM. The overall average PPM for the period is 84,000 PPM. The rejection showed decreasing trend but not significantly. As the actual rejection PPM doesn't meet the target PPM even in a single month. Hence it seemed like a chronic problem.

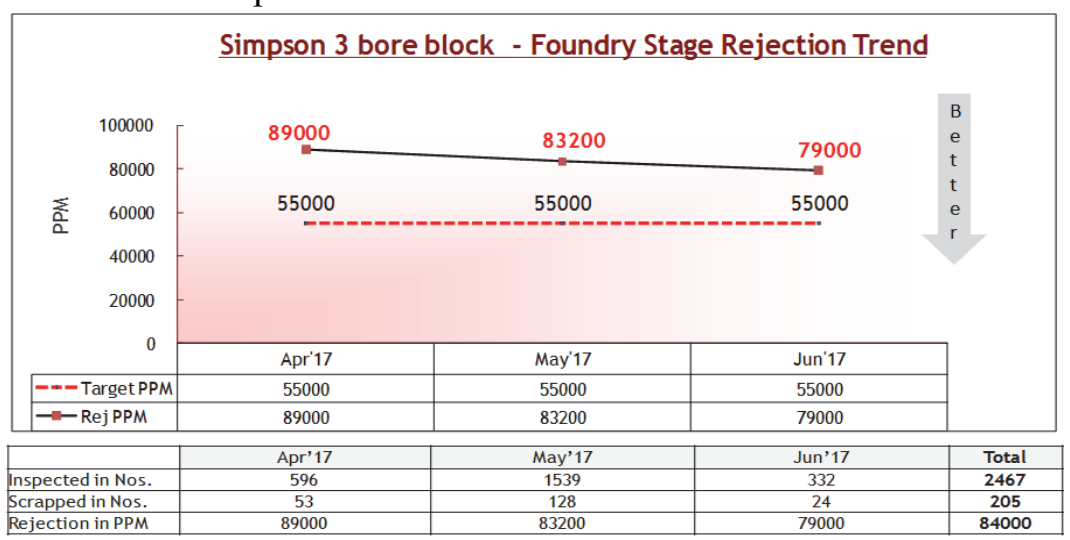

Fig. 4. 3-bore Block Foundry Rejection Trend 
Table 3 shows severity based on the four criteria namely- (a) Impact on customer satisfaction (b) Impact on quality (c) Impact on production, and (d) Impact on cost. The cylinder block SC is trending towards a high total severity of 31 , hence this part was selected for study.

Table 3

Severity Table to Justify the Problem selection

\begin{tabular}{lccccc}
\hline \multicolumn{1}{c}{$\begin{array}{c}\text { Defective } \\
\text { component }\end{array}$} & $\begin{array}{c}\text { Impact on } \\
\text { Customer } \\
\text { Satisfaction }\end{array}$ & $\begin{array}{c}\text { Impact on } \\
\text { Quality }\end{array}$ & $\begin{array}{c}\text { Impact on } \\
\text { Production }\end{array}$ & $\begin{array}{c}\text { Impact on } \\
\text { Cost }\end{array}$ & Total \\
\hline S3 Block & 9 & 8 & 6 & 8 & 31 \\
SJ3 Block & 5 & 5 & 5 & 5 & 20 \\
FT 35 & 5 & 5 & 3 & 3 & 16 \\
Bajaj Block & 5 & 5 & 2 & 2 & 14 \\
\hline
\end{tabular}

\section{Measure Phase}

This phase of data collection tells us about the "where we are" at initial stage. To know the number of component rejected the data was collected from each individual stage. Data collection was done to know about the current scenario of the rejection of the component and then it was further segregated to know major errors producing operation. The measure phase involves more numerical and data studies than the define phase.

\section{a) Probable cause of problem}

Fig. 5 shows cause \& effect diagram drawn for the Cylinder block with blow hole defect, the fish bone diagran drawn for four categories- Man, Machine, Method \& Material. The possible causes arrived from brainstorming process were fitted on each category of cause \& effect diagram. After analyzing the above results two sessions of brainstorming were organized to get different key points. In this brainstorming session there were 13 persons comprising of Engineers, Maintenance, Supervisors, Helper Operators, trainee and Shift in-charges were involved for this exercise, and different keys points were gathered through their experiences. The possible causes arrived from brainstorming process were fitted on each category of cause and effect diagram, also called as fish bone diagram.

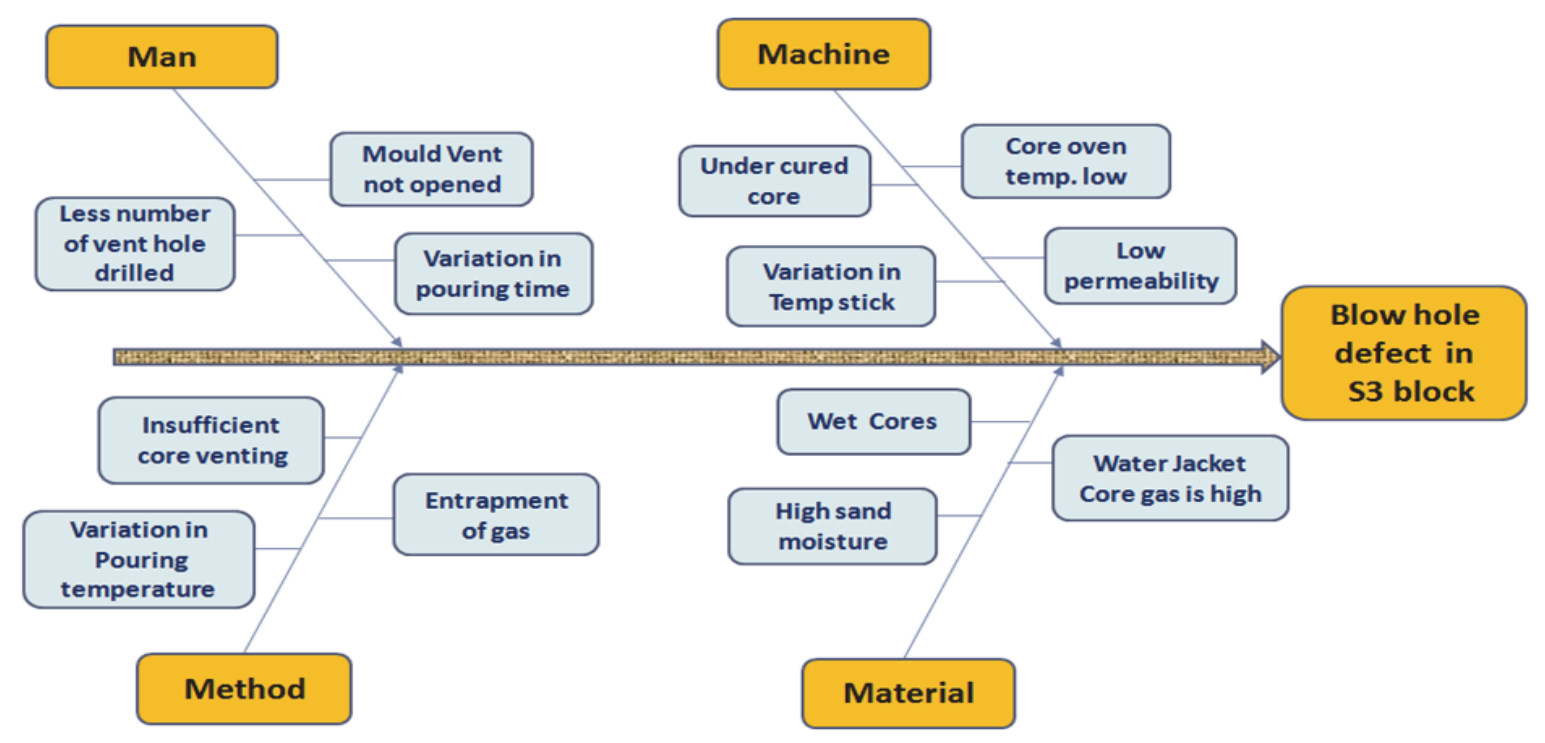

Fig. 5. Cause \& Effect diagram - Blow holes defect 
In Fig. 6, the pareto has been drawn for the possible causes after cause and effect matrix exercise. $80 \%$ of the causes taken for data collection are a) Water jacket core gas is high b) Variation in pouring temperature c) high sand-moisture and, d) Low permeability.

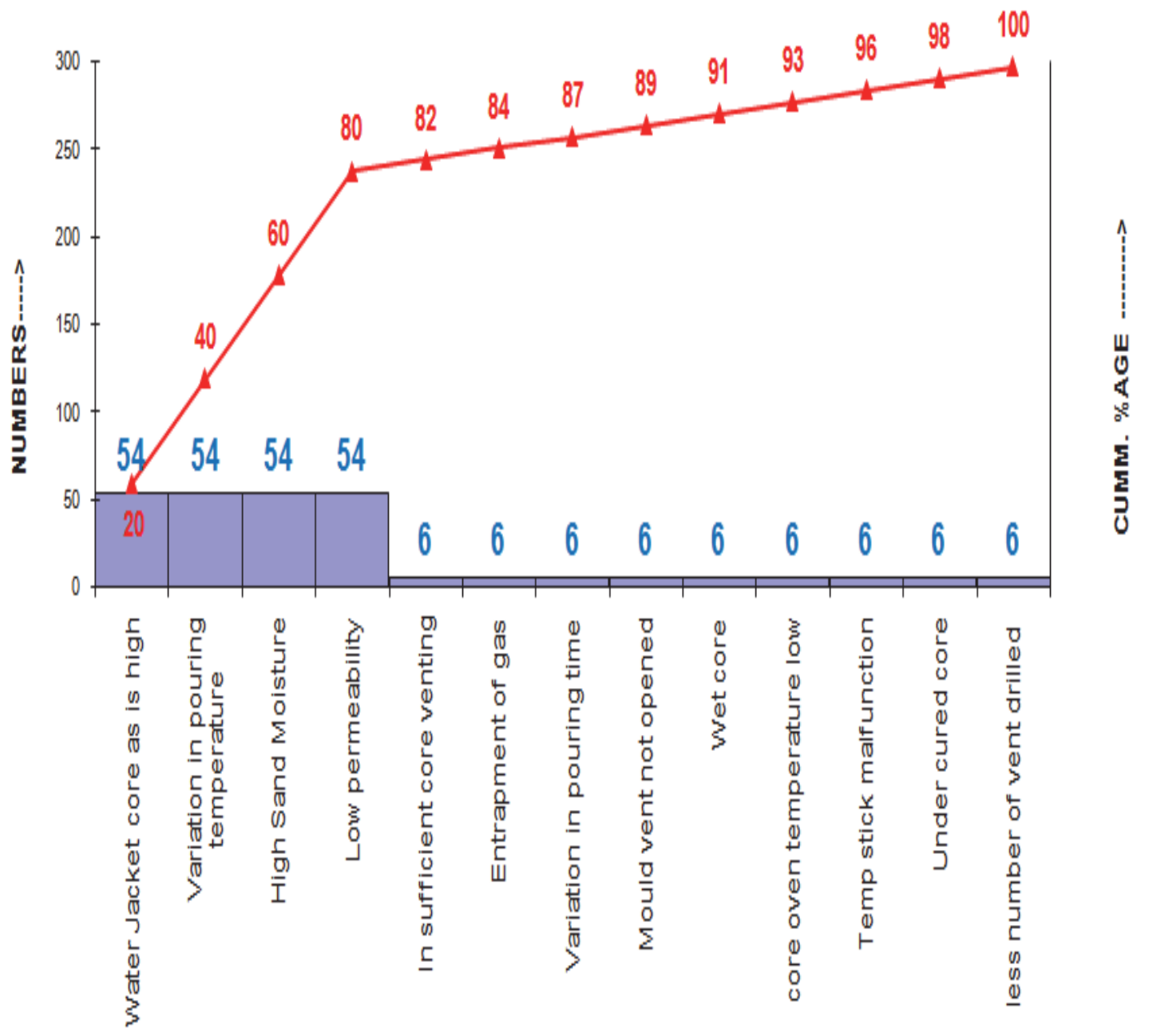

Fig. 6. Pareto on possible causes - Blowholes defect

Table 4 shows the operational definition for $\mathrm{Y}$ and $\mathrm{X}$ indicators.

\section{Table 4}

Operational definitions

\begin{tabular}{|c|c|c|}
\hline S. No. & Performance Indicator(Y) & Operational Definition \\
\hline Y1 & $\begin{array}{l}\text { Casting Scrap due to Blow Holes } \\
\text { Defect }\end{array}$ & $\begin{array}{l}\text { Defects in the casting due to blow holes and can be identified visu- } \\
\text { ally on the cope side surface of casting as per the limit sample. }\end{array}$ \\
\hline S. No. & Process Indicators & Operational Definition \\
\hline $\mathrm{X} 1$ & Water jacket core gas is high & Amount of gas in $1 \mathrm{gm}$ of cured core. \\
\hline $\mathrm{X} 2$ & Variation in pouring temperature & $\begin{array}{l}\text { Temperature taken at "Spout of Press Pour" at which a casting is } \\
\text { poured. }\end{array}$ \\
\hline $\mathrm{X} 3$ & High Sand Moisture & Amount of free moisture present in $100 \mathrm{gm}$ of molding sand. \\
\hline $\mathrm{X} 4$ & Low permeability & Property of mould that allows gases to escape from mould. \\
\hline
\end{tabular}

\section{b) Data Measurement Plan}

Table-5 shows the data measurement plan for the performance measure such as for a) Water jacket core gas is high b) High moulding sand moisture c) Low permeability d) Low pouring temperature. Data source, sample size, data collection techniques are indicated. 
Table 5

Data Measurement Plan

\begin{tabular}{|c|c|c|c|c|c|}
\hline Process/Input (X) & $\begin{array}{l}\text { Operational } \\
\text { Definition }\end{array}$ & $\begin{array}{c}\text { Data source and } \\
\text { location }\end{array}$ & Sample size & $\begin{array}{c}\text { Who will collect } \\
\text { the data }\end{array}$ & $\begin{array}{c}\text { How will data be col- } \\
\text { lected }\end{array}$ \\
\hline $\begin{array}{l}\text { Water Jacket core } \\
\text { gas is high }\end{array}$ & $\begin{array}{l}\text { Amount of gas } \\
\text { in } 1 \mathrm{gm} \text { of cured } \\
\text { core. }\end{array}$ & $\begin{array}{l}\text { Raw Material } \\
\text { Test Record and } \\
\text { laboratory }\end{array}$ & $\begin{array}{l}2 \text { Sample from } \\
\text { a lot }\end{array}$ & Lab Operator & Gas Evaluator \\
\hline $\begin{array}{l}\text { High Sand Mois- } \\
\text { ture }\end{array}$ & $\begin{array}{l}\text { Amount of free } \\
\text { moisture present } \\
\text { in } 100 \text { gm of } \\
\text { molding sand. }\end{array}$ & $\begin{array}{l}\text { Daily sand test- } \\
\text { ing parameter re- } \\
\text { port, } \mathrm{SC} / \mathrm{F}-201\end{array}$ & Once in a lot & Lab Tester & $\begin{array}{l}\text { Heater and Weighing } \\
\text { Balance Apparatus }\end{array}$ \\
\hline Low permeability & $\begin{array}{l}\text { Property of } \\
\text { mould that al- } \\
\text { lows gases to es- } \\
\text { cape from } \\
\text { mould. }\end{array}$ & $\begin{array}{l}\text { Daily sand test- } \\
\text { ing parameter re- } \\
\text { port, } \mathrm{SC} / \mathrm{F}-201\end{array}$ & Once in a lot & Lab Tester & Permeability Tester \\
\hline $\begin{array}{l}\text { Variation in pour- } \\
\text { ing temperature }\end{array}$ & $\begin{array}{l}\text { Temperature } \\
\text { taken at "Spout } \\
\text { of Press Pour" at } \\
\text { which a casting } \\
\text { is poured. }\end{array}$ & $\begin{array}{l}\text { Daily auto pour- } \\
\text { ing log sheet, } \\
\text { Lab/F-12 }\end{array}$ & $\begin{array}{l}2-3 \text { times in a } \\
\text { single lot }\end{array}$ & Lab Tester & $\begin{array}{l}\text { Lance and Temperature } \\
\text { meter }\end{array}$ \\
\hline
\end{tabular}

\section{Analyze Phase}

In analyze phase result of previous data collection by Pareto Analysis was analyzed. Then various tools of Six-Sigma were applied to find the solution of this problem.

The validation strategies for Blow-holes are:

i. Water Jacket core gas is high (Property of Core)

ii. Variation in Pouring Temperature (Property of Metal)

iii. High Sand Moisture (Property of Prepared Sand)

iv. Low Permeability (Property of Moulding Sand)

\section{a) Test of Validation}

To validate the data run chart for pouring temperature, Anderson - Darling Normality Test for Pouring Temperature, run chart for moisture, Anderson - Darling Normality Test for sand moisture, run chart for permeability, Anderson - Darling Normality Test for permeability and Residual plots for Blow holes has been prepared as shown in Fig. 7 to Fig. 13.

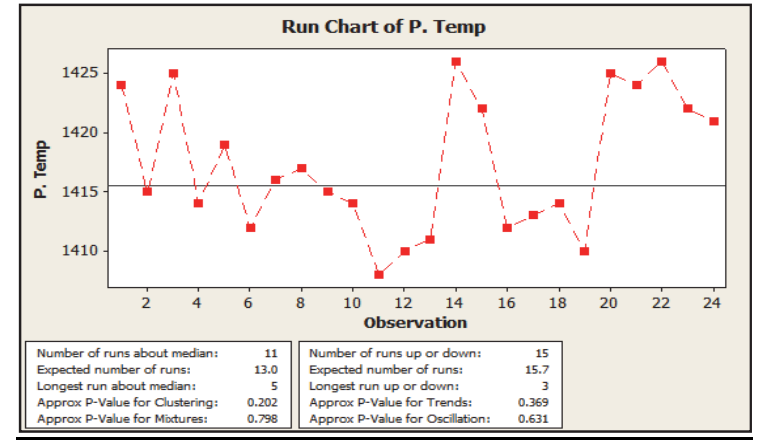

Fig. 7. Data Independence Test of Pouring Temperature

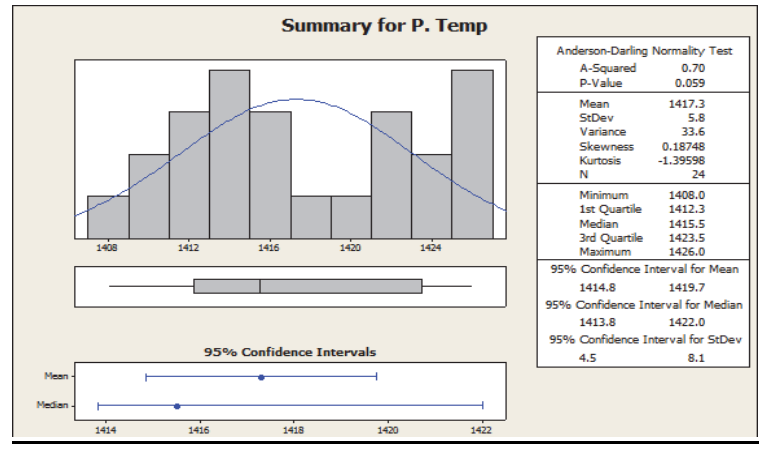

Fig. 8. Anderson - Darling Normality Test for Pouring Temperature

In Fig. 8, the run chart of pouring temperature shows that the Data is 'Random distributed' since all 4P's are $>0.05$. In Fig. 9, the normality test for pouring temperature shows that the Data is 'normal' since all Probabilty values exceed 5\%. 


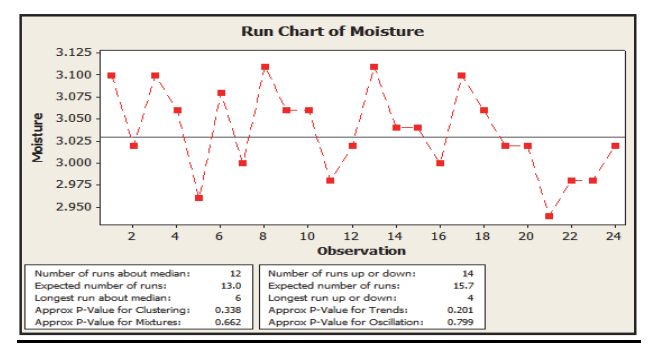

Fig. 9. Data Independence Test of Moisture



Fig. 10. Anderson - Darling Normality Test for Sand Moisture

In Fig. 10, the run chart of Sand Moisture shows that the Data is 'Random distributed' since all 4P's are $>0.05$. In Fig. 11, the normality test for Sand Moisture shows that the Data is 'normal' since all probability values exceed $5 \%$.



Fig. 11. Data Independence Test of Sand Permeability

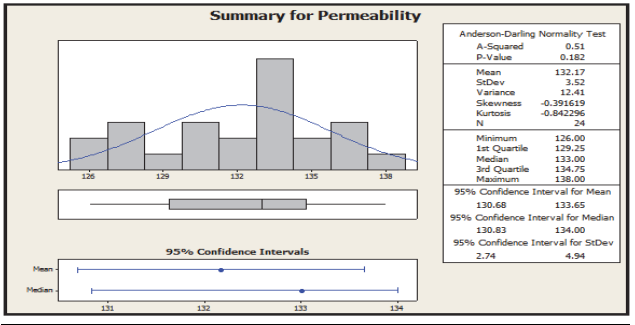

Fig. 12. Anderson - Darling Normality Test for Sand Permeability

In Fig. 12, the run chart of Sand Permeability shows that the Data is 'Random distributed' since all 4P's are $>0.05$. In Fig. 13, the normality test for Sand Permeability shows that the Data is 'normal' since all probability values exceed $5 \%$.

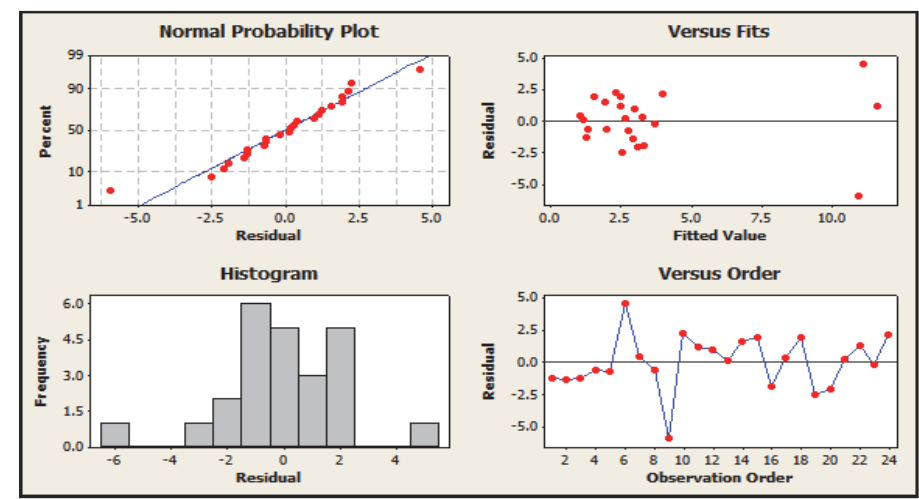

Fig. 13. Residual plots for Blow holes

In Fig. 14, the normal probability plot indicates Residual Vs Blow percent is normally distributed; No funnel effect in fitted value Vs Residual; Histogram of residuals follows bell shaped distribution.

\section{b) Root Cause of the problem}

Table- 6 shows the why-why technique to identify the solution for the water jacket area core gas high cause and the solution is 'low gas evolution sand to be used'.

Table 6

Identified root causes

\begin{tabular}{lllll}
\hline Valid Probable cause & Why? & Why? & Why? & Action \\
\hline $\begin{array}{l}\text { Water Jacket area core } \\
\text { gas is high }\end{array}$ & $\begin{array}{l}\text { Gas evolution by } \\
\text { Water Jacket core } \\
\text { was more. }\end{array}$ & $\begin{array}{l}\text { The water jacket core is made } \\
\text { by hot box process \& Gas evolu- } \\
\text { tion 16 to } 17 \mathrm{cc} / \mathrm{gm}\end{array}$ & $\begin{array}{l}\text { Process design } \\
\text { tion }\end{array}$ & $\begin{array}{l}\text { Low gas evolution sand to } \\
\text { be used. }\end{array}$ \\
\hline
\end{tabular}




\section{Improve Phase}

This phase finally recommends the remedial measure which is 'best under the circumstances'. Table 7 and Table 8 depict the three possible solutions. The advantage of using cold box process core of lesser gas evolution (10 to $11 \mathrm{cc} / \mathrm{gm}$ ) than hot box process, which is 16 to $17 \mathrm{cc} / \mathrm{gm}$. The disadvantage of cold box process is lesser tensile strength i.e. 130 PSI than hot box process core, which is 230 PSI.

\section{Table 7}

List of possible solutions

\begin{tabular}{lll}
\hline$\#$ & Xs validated & \multicolumn{1}{c}{ Possible solutions } \\
\hline 1. $\begin{array}{l}\text { Water jacket } \\
\text { core gas is high }\end{array}$ & 1.1. Low gas evolution cold box sand $(10$ to $11 \mathrm{cc} / \mathrm{gm})$ \\
& 1.2. Low gas evolution cold box sand $+20 \%$ chromate sand addition \\
& 1.3. Low gas evolution cold box sand $+20 \%$ chromate sand addition \\
\hline
\end{tabular}

\section{Table 8}

List of possible solutions

\begin{tabular}{|c|c|c|c|c|c|}
\hline Scope & \# & Trial & Trail Date & $\begin{array}{l}\text { Core Tensile } \\
\text { Strength in PSI }\end{array}$ & Status \\
\hline \multirow[t]{3}{*}{$\begin{array}{l}\text { S3 Block - } \\
\text { Water } \\
\text { Jacket Core }\end{array}$} & 1.1 & $\begin{array}{l}\text { Cold box sand } \\
(10 \text { to } 11 \mathrm{cc} / \mathrm{gm})\end{array}$ & $\begin{array}{l}1^{\text {st }} \text { week of } \\
\text { Aug'17 }\end{array}$ & 120 to 130 & $\begin{array}{l}\text { Core distortion observed very high, core } \\
\text { dimensionally got rejected. }\end{array}$ \\
\hline & 1.2 & $\begin{array}{l}\text { Cold box sand }+ \\
20 \% \text { Chromite } \\
\text { sand addition }\end{array}$ & $\begin{array}{l}1^{\text {st }} \text { week of } \\
\text { Aug'17 }\end{array}$ & 190 to 210 & $\begin{array}{l}\text { Core distortion observed moderately, } \\
\text { core, core dimensionally got rejected. }\end{array}$ \\
\hline & 1.3 & $\begin{array}{l}\text { Cold box sand + } \\
30 \% \text { Chromite } \\
\text { sand addition }\end{array}$ & $\begin{array}{l}\text { 1 }^{\text {st }} \text { week of } \\
\text { Aug'17 }\end{array}$ & 210 to 230 & $\begin{array}{l}\text { No Core distortion, Core dimension- } \\
\text { ally ok. }\end{array}$ \\
\hline
\end{tabular}

From the above trial it was observed that with $30 \%$ chromite sand addition the CTS is observed as 210 to 230 PSI, which is comparatively matching with CTS of water jacket as 200 to 220 PSI by hot box process. If the CTS is lower than 200 PSI may lead to water jacket core breakage.

\section{Control Phase}

In this phase, following follow-up actions are contemplated.

All learnings were documented \& Shared with all concerned.

$>$ Irreversible actions to eliminate the chances of failure.

$>$ Backup fixtures manufactured to prevent the chances of delay.

$>$ Process instructions made and displayed at production shop floor.

$>$ Operators were given training for new modified fixtures.

$>$ Operator's hourly work sheet were Upgraded.

\section{a) Full scale implementation plan}

Table 9 shows the full scale implementation on cold box water jacket core with $30 \%$ chromite sand. The result of blow hole defect is 5 numbers out of 408 numbers. The sigma level was $3.67 \%$ and full scale run is $1.22 \%$, there is a gain of $2.45 \%$. 
Table 9

Full scale implementation Plan

\begin{tabular}{llll}
\hline Output Indicator & Average & Sigma Level & DPMO \\
\hline Y1(Blow)-Before & $3.67 \%$ & 3.29 & 36670 \\
Y1(Blow)-Full scale run & $1.22 \%$ & 3.75 & 12255 \\
\hline
\end{tabular}

b) Sigma level before and after improvement

\begin{tabular}{|c|c|c|c|}
\hline \multicolumn{4}{|c|}{ Worksheet For Calculating Sigma Performance } \\
\hline & Overall Rejection - BEFORE PROJECT (Jun to Aug'15) & & enter \\
\hline 1 & Number Of Units Processed & $\mathrm{N}=$ & 2440 \\
\hline 2 & $\begin{array}{l}\text { Total Number Of Defects Made } \\
\text { (Include Defects Made And Later Fixed) }\end{array}$ & $\mathrm{D}=$ & 205 \\
\hline 3 & Number Of Defect Opportunities & $\mathrm{O}=$ & 1 \\
\hline & Per Unit & & \\
\hline 4 & Solve For Defects Per Million Opportunities & & 84016 \\
\hline 5 & Look Up Process Sigma In Abridged Sigma Conversion Table & Sigma level $=$ & 2.88 \\
\hline
\end{tabular}

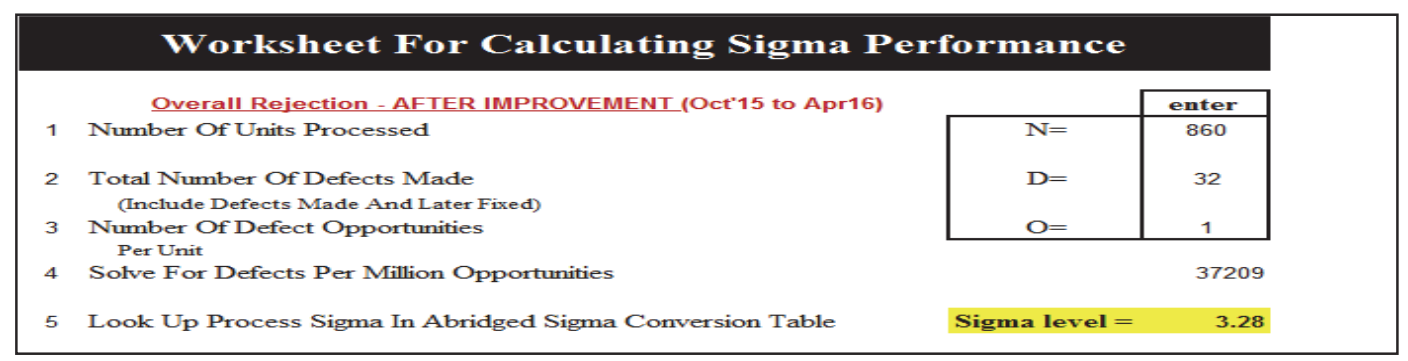

Fig. 14. Sigma Level of Overall rejection (Before \& Full scale Run)

In Fig. 14, the sigma level calculation of overall rejection before project and after full scale run are $2.88 \& 3.28$ respectively. There is an improvement in sigma level by 0.40 .

\section{Overall Improvement and Validation of overall Improvement}

a) Overall Rejection trend

In Fig. 15, the overall rejection trend shows reduction of rejection after quick win improvement and after reduction of blow hole defect. This can be seen during Aug'17 to Oct'17.
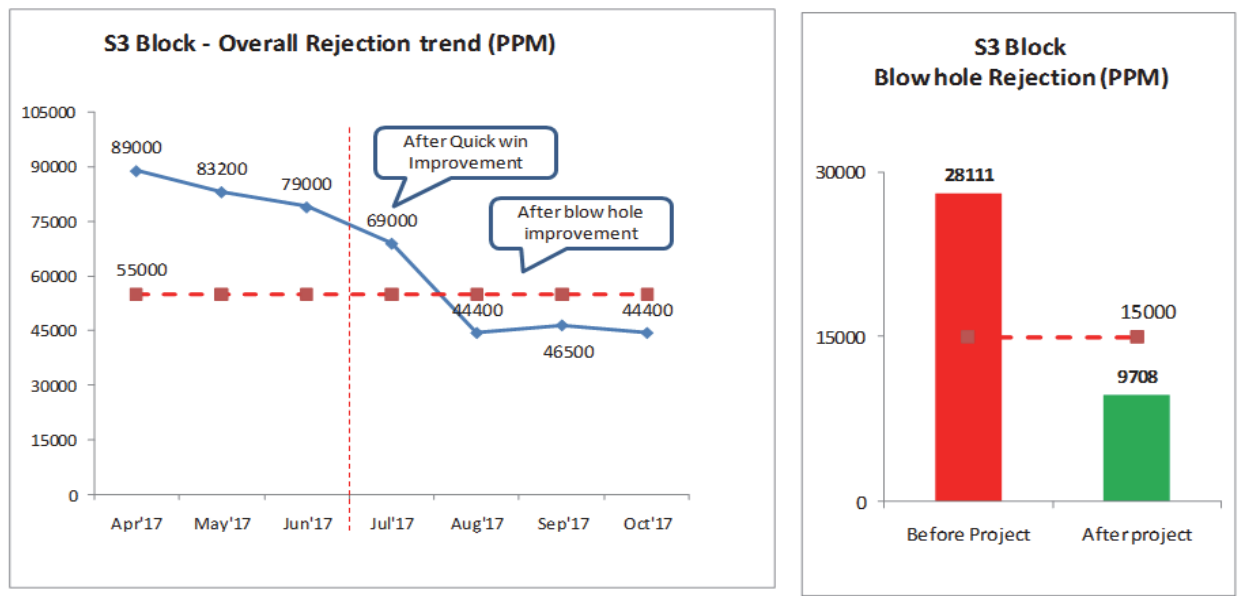

Fig. 15. Results of Overall Rejection Analysis 
Blow hole defect has been reduced from 28,111 PPM to 9,708 PPM, which is even less than the target.

b) Validation of overall Improvement

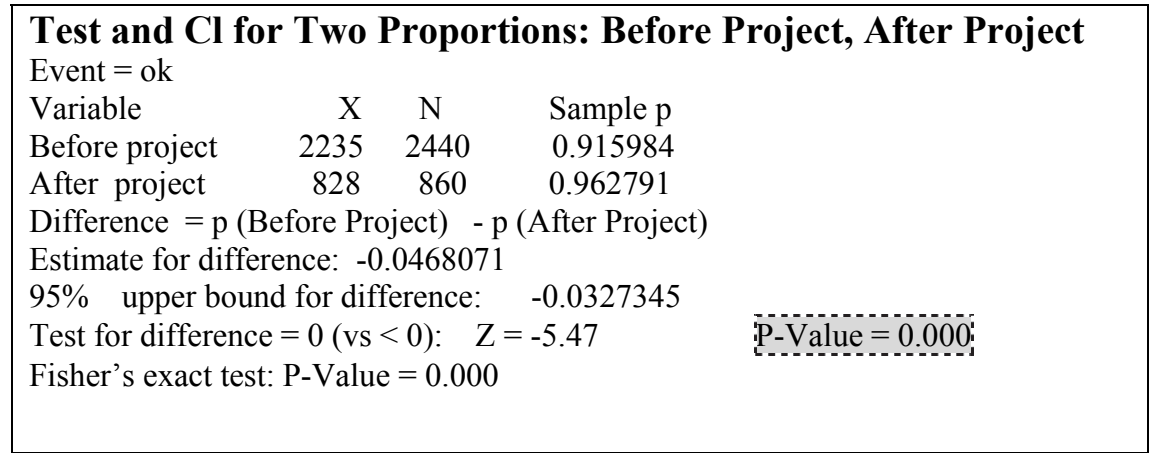

Fig. 16. Two Proportion Test for Overall Rejection

Statistical Problem statement:

Ho: Overall rejection in numbers before project is equal with overall rejection in numbers after project

Ha: Overall rejection in numbers after project is < overall rejection in numbers before project.

In the above figure- 16 , Since $\mathrm{P}$ value is 0.000 less than 0.05 , at $95 \%$ confidence level. It shows that null hypothesis is rejected ( $\mathrm{P}$ Low Null Go) \& we conclude that there is a significant improvement after implementing six sigma project.

\section{Cost Benefit Analysis, Conclusions and Limitations}

Results of investigation demonstrated that Six Sigma DMAIC approach significantly aimed at reducing rejections or improving sigma level through small improvements in the manufacturing system processes. Six Sigma has proven a universal approach of achieving major enhancements through system simplification and Organizational potential through incremental improvements. In the case under study, Pareto Analysis helped to predict the root cause of the problem and corrective actions have been taken to reduce high core gas area of water jacket. Implementation of DMAIC approach in the unit results in reduction of net PPM from 28,111 to 9,708 which results in net savings of rupees $12,56,640$ anually as shown in Table 10 .

Table 10

Cost Benefit Analysis

\begin{tabular}{cc}
\hline Casting weight & $77 \mathrm{~kg}$ \\
Selling price $/ \mathrm{kg}$ & INR 75 \\
Current level of blow holes & $8.37 \%$ (Average of Apr'17 to Jun'17) \\
Achieved level of blow holes & $5.08 \%$ (Average of Jul'17 to Oct'17) \\
Recovery of metal/kg & INR (75-35)= INR 40 \\
Reduction in defects & $8.4 \%-5.08 \%=3.35 \%$ \\
Production plan/month & 1000 Nos. \\
No. of Rejections/month & $(1000 / 100) * 3.35=34$ Nos. \\
Savings/annum & $(77 \mathrm{~kg}$ INR $40 * 34$ Nos.) 12 \\
& INR 12,56,640 \\
\hline
\end{tabular}

The selection of industry has been done on convenience sampling technique. The study can be expanded by implementing sophisticated integrated Six Sigma methodology like Lean Six Sigma which is the integration of lean manufacturing and Six Sigma. Moreover, there is possibility of method variance due to restricted area of research. 


\section{Scope of Future Work}

$>$ Comparative study between different industries for the components can be done with DMAIC Approach when both are manufacturing a same component.

$>$ Comparative study between the industries by using different tool/approaches to achieve the higher level of error free end product.

\section{References}

Aboelmaged, G. M. (2011). Reconstructing Six Sigma barriers in manufacturing and service organizations: The effects of organizational parameters. International Journal of Quality \& Reliability Management, 28(5), 519-541.

Al-Refaie, A., \& Al-Hmaideen, K. (2014). Six Sigma management and grey relational analysis to improve performance of tableting process. International Journal of Productivity and Quality Management, 15(1), 57-71.

Antony, J., Kumar, M., \& Madu, C. N. (2005). Six sigma in small-and medium-sized UK manufacturing enterprises: Some empirical observations. International Journal of Quality \& Reliability Management, 22(8), 860-874.

Antony, J., Singh Bhuller, A., Kumar, M., Mendibil, K., \& Montgomery, D. C. (2012). Application of Six Sigma DMAIC methodology in a transactional environment. International Journal of Quality \& Reliability Management, 29(1), 31-53.

Azis, Y., \& Osada, H. (2010). Innovation in management system by Six Sigma: an empirical study of world-class companies. International Journal of Lean Six Sigma, 1(3), 172-190.

Banuelas, R., Antony, J., \& Brace, M. (2005). An application of Six Sigma to reduce waste. Quality and Reliability Engineering International, 21(6), 553-570.

Bendell, T. (2006). A review and comparison of six sigma and the lean organisations. The TQM magazine, 18(3), 255-262.

Camgoz-Akdag, H. (2007). Total quality management through six sigma benchmarking: A case study. Benchmarking: An International Journal, 14(2), 186-201.

Chandna, P., \& Chandra, A. (2009). Quality tools to reduce crankshaft forging defects: an industrial case study. Journal of Industrial and Systems Engineering, 3(1), 27-37.

Chen, K. S., Hsu, C. H., \& Ouyang, L. Y. (2007). Applied product capability analysis chart in measure step of Six Sigma. Quality \& Quantity, 41(3), 387-400.

Choo, A. S., Linderman, K. W., \& Schroeder, R. G. (2007). Method and context perspectives on learning and knowledge creation in quality management. Journal of Operations Management, 25(4), 918-931.

Coronado, R. B., \& Antony, J. (2002). Critical success factors for the successful implementation of six sigma projects in organisations. The TQM magazine, 14(2), 92-99.

Edgeman, R. L., \& Bigio, D. (2004). Six Sigma in metaphor: heresy or holy writ?. Quality Progress, 37(1), 25-32.

Ganguly, K. (2012). Improvement process for rolling mill through the DMAIC six sigma approach. International Journal for Quality Research, 6(3), 221-231.

Gijo, E. V., \& Sarkar, A. (2013). Application of Six Sigma to improve the quality of the road for wind turbine installation. The TQM Journal, 25(3), 244-258.

Goh, T. N. (2002). A strategic assessment of Six Sigma. Quality and Reliability Engineering International, 18(5), 403-410.

Hu, M., Barth, B., \& Sears, R. (2005). Leveraging Six Sigma disciplines to drive improvement. International Journal of Six Sigma and Competitive Advantage, 1(2), 121-133.

Jaglan, P., Khanduja, D., \& Kaushik, P. (2013). Capacity waste at thermal power plants in India: a Six Sigma perception. International Journal of Six Sigma and Competitive Advantage, 8(1), 2233. 
Kovach, J. V., Cudney, E. A., \& Elrod, C. C. (2011). The use of continuous improvement techniques: A survey-based study of current practices. International Journal of Engineering, Science and Technology, 3(7), 89-100.

Kumar, S., Satsangi, P. S., \& Prajapati, D. R. (2011). Six Sigma an excellent tool for process improvement-a case study. International Journal of Scientific \& Engineering Research, 2(9), 110.

Kumar, S., Satsangi, P. S., \& Prajapati, D. R. (2013). Improvement of Sigma level of a foundry: a case study. The TQM Journal, 25(1), 29-43.

Kumara, V., \& Khandujaa, R. (2013). Application of Six-Sigma Methodology in SSI: A Case Study. International Journal of Current Engineering and Technology, 3(3), 971-976.

Kumaravadivel, A., \& Natarajan, U. (2011). Empirical study on employee job satisfaction upon implementing six sigma DMAIC methodology in Indian foundry-A case study. International Journal of Engineering, Science and Technology, 3(4).

Mahdi, O. R. A., \& Almsafir, M. K. (2012). Diagnosing of sustainable competitive advantage using Six Sigma methodology. International Journal of Business and Management, 7(7), 94.

Maleyeff, J., \& Kaminsky, F. C. (2002). Six Sigma and introductory statistics education. Education+ Training, 44(2), 82-89.

Matathil, A., Ganapathi, K. N., \& Ramachandran, K. (2012). Reduction of Scrap in an Electronic Assembly Line Using DMAIC Approach.

Pandey, A., \& Jain, K. K. Six Sigma in Manufacturing of Ingot Moulds in Foundry and Pattern Shop by Improving Sand Quality.

Patil, S. D., Ganganallimath, M. M., Math, R. B., \& Karigar, Y. (2015). Application of Six Sigma Method to Reduce Defects in Green Sand Casting Process: A Case Study. International Journal on Recent Technologies in Mechanical and Electrical Engineering (IJRMEE) ISSN, 2349-7947.

Pulakanam, V., \& Voges, K. E. (2010). Adoption of Six Sigma: review of empirical research. International Review of Business Research Papers, 6(5), 149-163.

Rajagopalan, R., Francis, M., \& Suárez, W. (2004). Managers at Work: Developing Novel Catalysts with Six Sigma. Research-Technology Management, 47(1), 13-16.

Salah, S., Rahim, A., \& Carretero, J. A. (2010). The integration of Six Sigma and lean management. International Journal of Lean Six Sigma, 1(3), 249-274.

Sambhe, R. U., \& Dalu, R. S. (2011). An empirical investigation of Six Sigma implementation in medium scale Indian automotive enterprises. International Journal of Productivity and Quality Management, 8(4), 480-501.

Shafer, S. M., \& Moeller, S. B. (2012). The effects of Six Sigma on corporate performance: An empirical investigation. Journal of Operations Management, 30(7-8), 521-532.

Shah, R., \& Ward, P. T. (2007). Defining and developing measures of lean production. Journal of Operations Management, 25(4), 785-805.

Singh, B. J., \& Khanduja, D. (2010). DMAICT: a road map to quick changeovers. International journal of Six Sigma and competitive advantage, 6(1-2), 31-52.

Snee, R. D. (2010). Lean Six Sigma-getting better all the time. International Journal of Lean Six Sigma, 1(1), 9-29.

Sokovic, M., Pavletic, D., \& Fakin, S. (2005). Application of Six Sigma methodology for process design. Journal of Materials Processing Technology, 162, 777-783.

Soti, A., Kaushal, O. P., \& Shankar, R. (2011). Modelling the barriers of Six Sigma using interpretive structural modelling. International Journal of Business Excellence, 4(1), 94-110.

Tennant, G. (2001). Six Sigma: SPC and TQM in manufacturing and services. Gower Publishing, Ltd.

Thomas, A., Barton, R., \& Byard, P. (2008). Developing a Six Sigma maintenance model. Journal of Quality in Maintenance Engineering, 14(3), 262-271.

Tiwari, S. K., Singh, R. K., \& Srivatava, S. C. (2016). Reduction of Reworks in Green Sand Casting Process: A Six Sigma Prospective. International Journal of Applied Engineering Research, 11(5), 3141-3150. 
Tolga Taner, M., Sezen, B., \& Antony, J. (2007). An overview of six sigma applications in healthcare industry. International Journal of Health Care Quality Assurance, 20(4), 329-340.

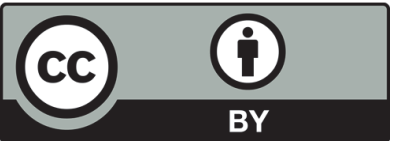

(C) 2019 by the authors; licensee Growing Science, Canada. This is an open access article distributed under the terms and conditions of the Creative Commons Attribution (CC-BY) license (http://creativecommons.org/licenses/by/4.0/). 